\title{
HUBUNGAN ANTARA DUKUNGAN KELUARGA DENGAN PEMBERIAN ASI EKSKLUSIF PADA BAYI USIA 0-6 BULAN
}

\author{
Siti Hamidah \\ Akademi Kebidanan Delima Persada \\ Gresik Email :siti_hamidahtw@yahoo.co.id
}

\begin{abstract}
ABSTRAK
Air Susu Ibu (ASI) merupakan makanan utama, alamiah dan terbaik untuk bayi, karena ASI mengandung hampir semua zat gizi dengan komposisi yang sesuai dengan kebutuhan dan tumbuh kembang. Namun cakupan ASI eksklusif di Indonesia masih rendah. Rendahnya pemberian ASI eksklusif dapat disebabkan karena rendahnya tingkat pendidikan dan pengetahuan, pekerjaan dan kepercayaan, ASI tidak keluar, puting susu lecet dan bengkak. Selain itu faktor keluarga yang tidak mendukung dalam pemberian ASI aksklusif, petugas kesehatan yang kurang mempromosikan dalam pelaksanaan managemen laktasi karena terpengaruh oleh promosi susu formula, atau bisa juga dari pengaruh sosial budaya yang negatif.

Tujuan dari penelitian ini adalah menganalisis hubungan antara dukungan keluarga dengan pemberian ASI eksklusif pada bayi usia 0-6 bulan.

Penelitian ini merupakan penelitian analitik denganpendekatancross sectional.Teknik sampling menggunakan accidental sampling dengan besar sampel 38 responden. Data dikumpulkan menggunakan cheklist dan di analisis secara komputasi menggunakan uji chi square dengan $\alpha=0.05$.

Hasil penelitian menunjukkan ada hubungan antara dukungan keluarga dengan pemberian ASI eksklusif pada bayi usia 0-6 bulan. Sehingga perlu tindakan peningkatan kesadaran dan pemberian dukungan pada ibu bersalin untuk memberikan ASI eksklusif melalui melibatkan keluarga.
\end{abstract}

Keyword : Air Susu Ibu (ASI), Dukungan Keluarga, Bayi

\section{PENDAHULUAN}

\subsection{Latar Belakang}

Pemberian air susuibusajaselama 6 bulan (ASI eksklusif), merupakan bagian penting dalam pembangunan sumberdaya manusia (SDM) Indonesia mulai sejak neonates dan bayi. Air Susu Ibu (ASI) merupakan makanan utama, alamiah dan terbaik untuk bayi, karena ASI mengandung hampir semua zat gizi dengan komposisi yang sesuai dengan kebutuhan dan tumbuh kembang. Namun Cakupan ASI eksklusif di Indonesia masih rendah. Berdasarkan pusat data dan informasi Kemenkes RI tahun 2014 diketahui bahwa cakupan bayi yang mendapat ASI eksklusif hanya sebesar 52,3\%. Sedangkan di Jawa Timur tahun 2014 diketahui cakupan bayi yang mendapat ASI eksklusif sebesar $74,0 \%$ meningkat dibanding $70,8 \%$ pada tahun
2013, dan belum dapat mencapai target yang ditetapkan sebesar $80 \%$.Menurut data dari Dinkes Kabupaten Gresik tahun 2014, diketahui bahwa cakupan dalam pemberian ASI eksklusif sebesar60,20\% dan belum dapat mencapai target (Kemenkes. 2014).

Hasil survey awal yang dilakukan oleh peneliti pada tanggal 6Juli 2015 di BPMSiti Hamidah, SST, M.Kes Gresikdengan membagikan kuesioner kepada $10 \mathrm{ibu}$, diperoleh 5 (50\%) ibu yang memberikan ASI secara eksklusif dan 5 (50\%) ibu yang tidak memberikan ASI secara eksklusif. Dari 5 ibu yang memberikan ASI eksklusif diketahui 2 (40 $\%)$ ibu yang mendapat dukungan dari keluarga dan 3 (60\%) ibu tidak mendapatkan dukungan dari keluarga, demikian juga dengan 5 ibu yang tidak memberikan ASI eksklusif diketahui 2 $(40 \%)$ ibu mendapat dukungan dari 
keluarga dan 3 (60\%) ibu tidak mendapat dukungan dari keluarga.

Rendahnya pemberian ASI eksklusif dapat disebabkan karena rendahnya tingkat pendidikan dan pengetahuan, pekerjaan dan kepercayaan, ASI tidak keluar, puting susu lecet dan bengkak. Selain itu faktor kaluarga yang tidak mendukung dalam pemberian ASI aksklusif, petugas kesehatan yang kurang mempromosikan dalam pelaksanaan managemen laktasi karena terpengaruh oleh promosi susu formula, atau bisa juga dari pengaruh sosial budaya yang negatif (Depkes RI, 2005).Dalam pemberian ASI eksklusif sangatlah dibutuhkan dukungan keluarga baik dari ibu, suami, mertua, atau saudara. Selain dukungan keluarga, dukungan lingkungan, keyakinan dan pengalaman masa lalu juga berpengaruh terhadap pemberian ASI eksklusif, tetapi dukungan keluarga merupakan dukungan yang paling utama dalam pemberian ASI eksklusif, karena dukungan merupakan unit dasar dalam masyarakat yang membentuk suatu hubungan kasih sayang antara manusia sehingga keluarga mempunyai peran penting dalam pemberian ASI eksklusif (Khairuddin, 2007).

Kegagalan pemberian ASI eksklusif akan menyebabkan jumlah sel otak sebanyak $15-20 \%$ sehingga menghambat perkembangan kecerdasan bayi pada tahap selanjutnya (Depkes RI, 2005). Apabila pada periode tersebut bayi dipaksa menerima makanan tambahan selain ASI, maka akan membahayakan bayi karena bayi belum mampu memproduksi enzim untuk mencerna makanan selain ASI, sehingga akan terjadi kembung, diare dan kemungkinan terkena ISPA lebih besar dibandingkan dengan bayi yang mendapatkan ASI eksklusif. Tentunya hal ini berakibat menghambat tumbuh kembang bayi.

Bagi ibu dengan memberikan ASI eksklusif dapat mengurangi perdarahan setelah persalinan, mempercepat proses involusi, menunda kesuburan, meringankan beban ekonomi dan mengurangi angka kejadian kanker payudara. Selain itu pemberian ASI eksklusif akan mempererat hubungan antara ibu dan bayi yang sangat penting untuk perkembangan psikis yang akan menenetukan kepribadian bayi tersebut kelak. Keuntungan lainnya, ASI dapat digunakan setiap saat, tersedia pada suhu ideal dan tidak perlu dipanaskan terlebih dahulu, segar dan bebas dari pencernaan kuman.Berdasarkan uraian diatas, pemberian ASI eksklusif di BPM Siti Hamidah masih rendah yang secara teori bisa dipengaruhi oleh dukungan keluarga, sehingga peneliti tertarik untuk meneliti tentang hubungan antara dukungan keluarga dengan pemberian ASI eksklusif pada bayi usia 0-6 bulan di BPM Siti Hamidah.

\subsection{Tujuan Penelitian}

Tujuan penelitian adalah menganalisis hubungan antara dukungan keluarga dengan pemberian ASI eksklusif pada bayi usia $0-6$ bulan di BPM Siti Hamidah.

\subsection{Metode}

Desain penelitian yang digunakan pada penelitian ini adalah analitik dengan pendekatan cross sectional. Karena peneliti menekankan pada waktu pengukuran/observasi data variabel independen dan dependen diukur pada saat yang sama. Jumlah sampel sebanyak 38 diambil dengan teknik sampling aksidental. Variabel independen dalam penelitian ini adalah dukungan keluarga, sedangkan variabel dependen adalah pemberian ASI eksklusif pada bayi usia $0-6$ bulan. Data di ambil menggunakan checklist, dan dianalisis secara komputasi menggunakan uji chi square dengan $\alpha=0.05$. 


\section{PEMBAHASAN}

Hasil penelitian ini akan memaparkan data umum yang terdiri dari umur, pendidikan dan pekerjaan serta data khusus meliputi dukungan keluarga dan pemberian ASI eksklusif.

\subsection{Karakteristik Responden}

Berikut ini akan disajikan data umum penelitian berupa karakteristik usia, pendidikan dan pekerjaan responden.

a. Karakteristik

responden berdasarkan umur

Tabel 1 Karakteristik

Responden

Berdasarkan Umur di BPM Siti Hamidah,SST,M.Kes Gresik Tahun 2015

\begin{tabular}{ccc}
\hline Usia & Frekuensi & $\mathbf{( \% )}$ \\
\hline$<20$ tahun & 12 & 31,6 \\
$20-35$ tahun & 25 & 65,8 \\
$>35$ tahun & 1 & 2,6 \\
\hline Jumlah & 38 & 100 \\
\hline
\end{tabular}

Hasil pengumpulan data pada tabel 1

menunjukkan bahwa sebagian besar responden berusia 21-35 tahun yaitu sebanyak 25 responden $(65,8 \%)$ dan hanya 1 respoden $(2,6 \%)$.

\section{b. Karakteristik} responden berdasarkan pendidikan

Pendidikan responden dikategorikan menjadi 4 kelompok yaitu SD, SMP, SMA, Akademi/PT.

Tabel 2 Karakteristik

Responden

Berdasarkan Pendidikan di BPM Siti Hamidah,SST,M.Kes Gresik Tahun 2015

\begin{tabular}{lcc}
\multicolumn{1}{c}{ Pendidikan } & Frekuensi & $(\boldsymbol{\%})$ \\
\hline SD & 8 & 21,1 \\
SMP & 5 & 13,2 \\
SMA & 24 & 63,1
\end{tabular}

\begin{tabular}{ccc} 
Akademi/PT & 1 & 2,6 \\
\hline Jumlah & 38 & 100
\end{tabular}

Hasil pengumpulan data pada tabel 2 menunjukkan bahwa sebagian besar responden berpendidikan SMA yaitu sebanyak $(63,1 \%)$.

\section{c. Karakteristik}

responden berdasarkan pekerjaan

Jenis pekerjaan dikategorikan menjadi 4 yaitu pegawai swasta, wiraswasta, PNS dan tidak bekerja.

Tabel 3 Karakteristik Responden Berdasarkan Pekerjaan di BPM Siti Hamidah,SST,M.Kes Gresik Tahun 2015

\begin{tabular}{lcc}
\hline \multicolumn{1}{c}{ Pekerjaan } & Frekuensi & $(\boldsymbol{\%})$ \\
\hline Pegawai swasta & 22 & 57,9 \\
Wiraswasta & 8 & 21,1 \\
PNS & 1 & 2,6 \\
Tidak bekerja & 7 & 18,4 \\
\hline \multicolumn{1}{c}{ Jumlah } & 38 & 100 \\
\hline
\end{tabular}

Hasil pengumpulan data pada tabel 3 menunjukkan bahwa sebagian besar responden adalah pegawai swasta yaitu sebanyak 22 responden $(57,9 \%)$.

\subsection{Data Khusus}

Berikut ini akan disajikan hasil penelitian data khusus berupa variabel yang diteliti yaitu dukungan keluarga dan pemberian ASI eksklusif.

\section{a. Dukungan keluarga Pada Ibu Menyusui}


Dukungan keluarga dibedakan menjadi mendukung dan tidak mendukung sebagai berikut :

Tabel 4 Distribusi Frekuensi Berdasarkan

Dukungan Keluarga Pada Ibu

Menyusui di BPM Siti Hamidah,SST,M.Kes Gresik

Tahun 2015

\begin{tabular}{lcc}
\hline \multicolumn{1}{c}{ Dukungan } & Frekuensi & $\mathbf{( \% )}$ \\
Keluarga & & \\
\hline Mendukung & 17 & 44,7 \\
Tidak mendukung & 21 & 55,3 \\
\hline \multicolumn{1}{c}{ Jumlah } & 38 & 100 \\
\hline
\end{tabular}

Hasil pengumpulaan data pada tabel 4 menunjukkan bahwa sebagian besar responden tidak mendapat dukungankeluarga yaitu sebanyak 21 responden $(55,3 \%)$.

\section{b. Pemberian ASI eksklusif}

Tabel 5 Pemberian ASI Eksklusif di BPM Siti Hamidah,SST,M.Kes Gresik Tahun 2015

\begin{tabular}{lcc}
\hline $\begin{array}{c}\text { Pemberian ASI } \\
\text { Eksklusif }\end{array}$ & Frekuensi & $\mathbf{( \% )}$ \\
\hline Memberi & 12 & 31.6 \\
Tidak memberi & 26 & 68,4 \\
\hline \multicolumn{1}{c}{ Jumlah } & 38 & 100 \\
\hline
\end{tabular}

Hasil pengumpulan data pada tabel 5 menunjukkan bahwa sebagian besar responden tidak memberi ASI eksklusif yaitu sebanyak 26 responden $(68,4 \%)$.

\section{c. Tabulasi silang antara dukungan keluarga dengan pemberian ASI eksklusif}

Tabulasi silang antara dukungan keluarga dengan pemberian ASI eksklusif bisa dilihat pada tabel 6 sebagai berikut : Tabel 6 Tabulasi Silang Hubungan antara Dukungan Keluarga Dengan
Pemberian ASI Eksklusif Pada Bayi Usia 0-6 Bulan di BPM Siti Hamidah,SST,M.Kes Gresik Tahun 2015

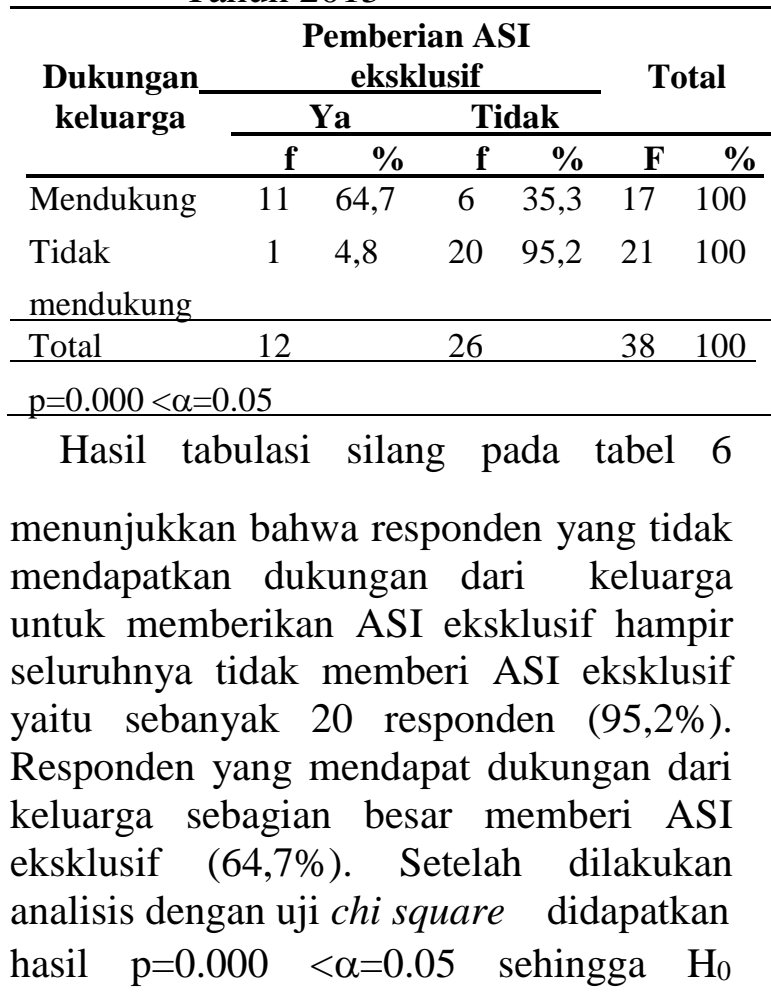

ditolak yang artinya ada hubungan antara dukungan keluarga terhadap pemberian ASI eksklusif pada bayi usia 0-6 bulan.

\subsection{PEMBAHASAN}

\section{Dukungan Keluarga}

Berdasarkan hasil penelitian menununjukkan sebagian besar keluarga ibu tidak mendukung dalam pemberian ASI eksklusif (55,3\%). Dari semua dukungan yang diberikan keluarga, dukungan penghargaan adalah hal yang paling jarang diberikan. Hal ini didukung dengan ditemukannya $(28,9 \%)$ keluarga ibu kurang empati dengan tidak pernah 
memijat ibu ketika ibu kelelahan setelah seharian merawat bayi. Hal ini disebabkan karena keluarga merasa tidak terbiasa untuk mengungkapkannya.

Dukungan penghargaan atau pujian merupakan hal yang penting dalam kehidupan sebuah keluarga. Dengan dukungan penghargaan, orang menyatakan penghargaan dan penilaian positif terhadap orang lain. Dengan memberi dorongan dan dukungan terhadap perasaan dan gagasan yang dinilai baik pada seseorang, akan secara tidak langsung menunjukkan kelebihan dan keunggulan orang tersebut. Dukungan penghargaan mengembangkan rasa percaya diri pada orang yang menerimanya. Tapi karena tidak terbiasa, dukungan ini jarang atau bahkan tidak pernah diberikan.

Dukungan keluarga sangat diperlukan oleh ibu dalam merawat bayi. Dukungan yang dibutuhkan oleh ibu bisa dari suami, orang tua, mertua, saudara atau keluarga yang lain, apabila keluarga tidak mendukung dapat mempengaruhi sikap dan perilaku ibu. Jika keluarga memberi dukungan kepada ibu, ibu akan termotivasi untuk melakukan suatu tindakan dikarenakan adanya keyakinan maka akan timbul percaya diri, semangat dan niat dalam diri ibu sehingga ibu akan mempunyai keinginan besar untuk mendapatkan suatu hal yang diingankan sesuai dengan yang diharapkan, dan begitu juga sebaliknya. Dalam suatu tindakan, ibu yang mempunyai keinginan akan lebih berhasil daripada ibu yang tidak mempunyai keinginan.

Dengan adanya dukungan yang diberikan dari orang-orang terdekat diharapkan dapat mendorong terjadinya perubahan perilaku yang terwujud dalam dukungan keluarga, sehingga dukungan keluarga sangat penting bagi ibu dalam membetuk suatu tindakan. Menurut Green (1980) diungkapkan bahwa perilaku seseorang tentang kesehatan terbentuk dari tiga faktor, salah satunya faktor penguat, faktor yang diperoleh dari orang terdekat dan adanya dukungan sosial yang diberikan ke individu tersebut seperti keluarga, teman maupun dari petugas kesehatan yang dapat memperkuat perilaku (Notoatmodjo, 2010).

Hal ini diperkuat dengan teori yang diberikan oleh Prasetyo (2009) yang menyatakan dukungan keluarga adalah sikap-sikap penuh pengertian yang ditunjukkan dalam bentuk kerja sama yang positif serta memberikan dukungan moral maupun emosional sedangkan menurut Muhibin (2008) salah satu bentuk dukungan adalah dukungan penghargaan atau penilaian merupakan dukungan yang berupa penilaian positif dari keluarga lewat ungkapan hormat, diantaranya memberikan support, pengakuan, penghargaan dan perhatian kepada ibu. 


\section{Pemberian ASI Eksklusif}

Hasil penelitian menunjukkan sebagian besar ibu tidak memberikan ASI eksklusif $(68,4 \%)$. Dari data ini dapat diidentifikasi bahwa ibu yang tidak memberikan ASI secara eksklusif kepada bayinya lebih banyak dibandingkan ibu yang memberikan ASI eksklusif. Banyaknya ibu yang tidak memberikan ASI eksklusif kepada bayinya dapat disebabkan karena pekerjaan yang ditunjang oleh data yang terdapat pada tabel 4.3 sebagian besar $(57,9 \%)$ ibu adalah pegawai swasta sehingga ibu sering meninggalkan bayinya dirumah selama bekerja dan karena sibuk bekerja maka ibu merasa lelah dan kerepotan bila harus memberi ASI eksklusif pada bayinya sehingga hal ini akan menyebabkan rendahnya pemberian ASI secara eksklusif.

Pekerjaan bukanlah suatu hal yang yang dapat menghambat ibu dalam memberikan ASI secara eksklusif, dalam bekerjapun ibu dapat memberikan ASI secara eksklusif. Misalnya ASI dapat diberikan secara tidak langsung yaitu dapat dilakukan dengan cara memeras atau memompa ASI, lalu menyimpannya untuk kemudian diberikan kepada bayinya. Kunci keberhasilan ASI eksklusif bagi ibu adalah manajemen ASI yang baik. Manajemen ASI disini bukan hanya seputar teknik laktasi, namun juga meliputi bagaimana ibu menyiapkan diri dan lingkungannya sebelum ibu kembai bekerja.

Dalam hal ini perlu adanya pemhaman yang harus dimiliki oleh ibu. Begitu pentingnya pemberian ASI eksklusif pada bayi usia 0-6 bulan, karena ASI mempunyai peranan penting untuk menjaga daya tahan tubuh bayi terhadap penyakit sehingga bayi lebih jarang sakit karena ASI eksklusif lebih higienis dan kebutuhan gizi yang diperlukan oleh bayi terpenuhi bayi dapat tumbuh dan berkembang secara optimal.

Menurut Maryunani (2012) menyatakan bahwa salah satu faktor dalam pemberian ASI eksklusif adalah kurangnya fasilitas yang mendukung laktasi di tempat kerja. Pekerjaan umumnya merupakan hal penting dan cenderung menyita waktu serta memerlukan aktivitas. Dengan begitu tempat bekerja mempengaruhi terhadap ibu dalam memberikan ASI eksklusif dimana tempat pekerjaan akan membantu tersedianya tempat bagi ibu untuk memberikan ASI bagi bayinya. Sedangkan menurut Thomas yang dikutip oleh Nursalam (2008), pekerjaan itu sendiri adalah kebutuhan yang harus dilakukan terutama untuk menunjang kehidupannya dan kehidupan keluarga.

Maka dari itu perlu diberikan informasi tentang pentingnya pemberian ASI eksklusif untuk bayi usia 0-6 bulan tidak 
hanya melalui pendidikan formal tetapi juga dapat diperoleh dari pendidikan non formal, dari media cetak (koran, majalah), media elektronik (televisi, internet), konseling dan penyuluhan yang diberikan oleh petugas kesehatan dan dari pengalaman serta dari lingkungan dimana orang tersebut tinggal. Sehingga ibu termotivasi untuk memberikan ASI eksklusif pada bayinya sampai usia 6 bulan tanpa memberikan makanan pendamping ASI.

Dengan adanya keyakinan maka akan timbul percaya diri pada ibu, sehingga ibu yang berkeinginan besar untuk memberikan ASI eksklusif pada bayinya akan lebih berhasil, dibandingkan dengan ibu yang kurang mempunyai keinginan besar untuk memberikan ASI eksklusif pada bayinya.

\section{Hubungan Antara Dukungan Keluarga dengan Pemberian ASI Eksklusif pada Bayi Usia 0-6 Bulan di BPM Siti Hamidah, SST,M.Kes Gresik}

Berdasarkan hasil tabulasi silang dukungan keluarga dengan pemberian ASI eksklusif pada bayi usia 0-6 bulan menunjukkan ibu yang tidak mendapatkan dukungan dari keluarga hampir seluruhnya tidak memberi ASI eksklusif $(95,2 \%)$ dan ibu yang mendapat dukungan dari keluarga sebagian besar memberi ASI eksklusif pada bayinya $(64,7 \%)$. Sedangkan hasil uji chi square didapatkan nilai $\mathrm{p}=0.000$ $<\alpha=0.05$, hal ini berarti $\mathrm{H}_{0}$ ditolak yang artinya ada hubungan antara dukungan keluarga dengan pemberian ASI eksklusif pada bayi usia $0-6$ bulan.

Pada umumnya keluarga di Indonesia menganut tipe paternalistik, dimana ada anggapan bahwa yang lebih tua harus dipatuhi. Keluarga dapat menjadi faktor yang sangat berpengaruh dalam menentukan keyakinan dan nilai kesehatan individu. dalam hal ini pengaruh keluarga terutama orang tua yang memberikan anjuran agar memberi makanan pendamping ASI pada bayi, maka ibu akan mematuhi anjuran tersebut dengan memberikan makanan pendamping ASI secara dini pada bayinya sesuai keyakinannya yang telah turun-temurun.

Akibatnya produksi ASI akan berkurang, bayi menjadi terbiasa dengan pemberian makanan pendamping ASI yang nilai gizinya lebih sedikit dibandingkan dengan ASI sehingga menghambat pertumbuhan dan perkembangan bayi.

Keluarga merupakan unit terkecil dari masyarakat yang terdiri atas kepala keluarga dan beberapa orang yang berkumpul dan tinggal disuatu tempat dibawah suatu atap dalam keadaan saling ketergantungan (Depkes RI, 2005). Dukungan merupakan informasi atau nasihat verbal atau non verbal, bantuan nyata atau tindakan yang diberikan oleh 
keakraban yang didapat karena kehadiran mereka dan mempunyai manfaat emosional atau efek perilaku bagi pihak penerima (Bart Smeat, 2003).

Dalam hal ini orang yang merasa lega karena diperhatikan, mendapatkan saran atau kesan yang menyenangkan pada dirinya seperti halnya ibu menyusui, semakin tinggi dukungan keluarga terhadap ibu untuk memberikan ASI secara eksklusif maka akan menimbulkan kesadaran dan keinginan ibu untuk lebih memberikan ASI secara eksklusif selama 6 bulan yang akan mendapatkan kekebalan dan nutrisi yang lebih. Demikian sebaliknya dukungan keluarga yang kurang tentang pemberian ASI eksklusif menyebabkan responden cenderung tidak akan memberikan ASI secara eksklusif.

Dalam teori Effendi (2008), ada beberapa hal yang dapat memungkinkan keberhasilan pemberian ASI eksklusif oleh ibu terhadap bayinya dapat dilakukan melalui 3 strategi, yaitu strategi pertama adalah advokasi kepada para pengambil keputusan agar dapat memberikan dukungan atau kebijakan, arahan, bantuan yang nyata agar terwujud program ASI eksklusif. Strategi kedua adalah pemberdayaan ibu menyusui, keluarga dan masyarakat tentang pentingnya ASI eksklusif yang dapat dilakukan melalui tatap muka, demonstrasi di tempat ibu berkumpul seperti arisan, pengajian, rapat
PKK maupun penyuluhan ASI dengan menggunakan media cetak maupun media elektronik agar dapat mencapai sasaran yang luas.

Strategi ketiga adalah dengan melakukan pendekatan terhadap berbagai lembaga swadaya masyarakat, berbagai macam organisasi sosial masyarakat dengan tujuan agar beberapa lembaga tersebut dapat berpartisipasi langsung untuk meningkatkan pengetahuan, kesadaran, kemauan dan kemampuan ibu dalam berperilaku untuk menyusui bayinya dengan ASI saja sampai bayi usia 6 bulan.

Disinilah peran keluarga sangat penting untuk memberikan suatu dukungan dalam pemberian ASI eksklusif. Mengingat ASI eksklusif merupakan hal yang sangat penting bagi kesehatan bayi untuk saat ini dan yang akan datang.

\section{SIMPULAN}

\subsection{SIMPULAN}

Berdasarkan hasil penelitian dan pembahasan mengenai hubungan antara dukungan keluarga dengan pemberian ASI eksklusif pada bayi usia 0-6 bulan di BPM Siti Hamidah, SST,M.Kes, dapat dirumuskan simpulan sebagai berikut :

1. Sebagian besar keluarga tidak mendukung dalam pemberian ASI eksklusif

2. Sebagian besar ibu tidak memberi ASI eksklusif pada bayi usia 0-6 bulan 
3. Ada hubungan antara dukungan keluarga dengan pemberian ASI eksklusif pada bayi usia 0-6 bulan

\subsection{SARAN}

Upaya untuk memotivasi keluarga agar memberikan dukungan pada ibu dalam pemberian ASI eksklusif pada bayi usia 06 bulan, saran yang diberikan adalah sebagai berikut ;

\section{Bagi Institusi Pendidikan}

Perlunya dilakukan kegiatan pengabdian kepada masyarakat berupa penyuluhan tentang pentingnya ASI eksklusif dan dampak apabila tidak diberikan. Pada saat pemeriksaan kehamilan, kelas ibu hamil, posyandu melibatkan keluarga.

\section{Bagi Tempat Penelitian}

Meningkatkan kesadaran dan pemberian dukungan pada ibu akan pentingnya ASI eksklusif dengan melibatkan keluarga agar keberhasilan menyusui bayi sampai 6 bulan dapat tercapai, sehingga bayi dapat tumbuh dan berkembang secara optimal dan upaya untuk perbaikan gizi terpenuhi sehingga Angka Kematian Bayi (AKB) semakin menurun.

\section{DAFTAR PUSTAKA}

Depkes RI. 2005. Bila Anda Ingin Bayi yang Sehat. Jakarta : Depkes Dirjen PKM
- 2005. Pedoman Pemberian

Makanan Pendamping ASI.

Jakarta : Dirjen PKM

Effendy, N. 2008. Dasar-Dasar Kesehatan Masyarakat. Jakarta : EGC

Khoirudin. 2007. Pemberian Makanan Untuk Bayi. Jakarta : Perinesia

Maryunani, Anik. 2012. InisiasiMenyusuiDini ASI EksklusifdanManajemenLaktasi.J akarta : TIM

Muhibbin. 2008. Psikologi Perkembangan. Jakarta : EGC

Nursalam. 2008. Pendekatan Praktis Metodelogi Riset Keperawatan. Jakarta : Salemba Medika

Notoatmodjo, Soekidjo. 2010.Pengantar Pendidikan Kesehatan dan Ilmu Perilaku. Jakarta : Rineka Cipta

Prasetyo. 2009. Buku Pintar ASI Eksklusif. Jakarta : DIVA BINA 